Russian Federation. Moscow State University of Geodesy and Cartography. URL: http://cced-complete.com/deliverables/wp2_competence_ model_russia_eng.pdf

2. Wilcox Y. An Initial Study to Develop Instruments and Validate the Essential Competencies for Program Evaluators (ECPE): A dissertation submitted to the faculty of the Draduate school of the university of Minnesota. June, 2012. 160 p.

3. Competency Model. Valamis. May 21, 2019. URL: https://www.valamis.com/hub/ competency-model

DOI https://doi.org/10.30525/978-9934-26-045-2-8

\title{
ЩОДО СУТНІСНИХ СКЛАДОВИХ ПРЕДСТАВНИЦЬКОГО ЛІДЕРСТВА
}

\begin{abstract}
Пашко Л. А.
доктор наук з державного управління, професор, професор кафедри політологї, управління та державної безпеки Волинського національного університету імені Лесі Українки м. Луиькк, Україна
\end{abstract}

У європейській традиції публічного управління десятиліттями існує сучасна практика офіційного визнання посадової особи лідером. Причому зрозуміло, що не йдеться ні про автоматичне ототожнення поняття «посадова особа» 3 поняттям «лідер», ні про банальний перелік лідерських якостей. Мова йде про офіційне визнання сутності сучасного представницького лідерства як професійного служіння громадянам.

Такий підхід сприяв успішному запровадженню лідерства в органах представницької влади в країнах-членах Ради Свропи. А це зобов'язало кожну посадову особу не лише до постійного особистісного лідерського самовдосконалення, а й щоденної лідерської самореалізації у форматі: «Керівник = Особистість = Лідер команди співробітників = Лідер територіальної громади». Такий сутнісний формат надає сучасному посадовцю-професіоналу простір для максимальної власної ефективної й результативної самореалізації як відповідального лідера на усіх рівнях: особистісному, командному, інституційному, громадівському [1]. 
Для вітчизняної системи представницької влади такий підхід постає надзвичайно актуальним і своєчасним саме тому, що успішність децентралізації державної влади безпосередньо залежить від якості представницьких лідерів, зобов'язаних професійно та професіонально служити громаді, країні, державі.

Зрозуміло, що таке представницьке лідерське служіння потребує постійної, невтомної, безперервної, зацікавленої самоосвіти та опанування сучасними знаннями, вміннями та навичками 3 проблематики управлінського в цілому i представницького лідерства зокрема. Підтвердженням цьому є слушна думка М. Вебера про необхідність пошуків важливих детермінант макроісторичних процесів у мікросфері людських мотивацій, цінностей, відносин та орієнтація при цьому на типові мотиви й типові зразки соціальної дії.

В сучасних умовах функціонування Української держави представницьке лідерство постає надзвичайно актуальним. Саме тому воно має стати передумовою:

- розуміння складності та вагомості управлінської праці у представницьких органах влади;

- визнання пріоритетної ролі суб'єкта владних повноважень як організатора командної взаємодії не лише колективу однодумців, а й усіх зацікавлених сторін;

- усвідомлення необхідних професіонально-професійноособистісних характеристик посадових осіб та депутатів усіх рівнів.

Запровадження представницького лідерства дозволить:

- Визначити та визнати сутнісні характеристики управлінського лідерства сучасного суб'єкта владних повноважень.

- Розуміти основні характеристики предметів та продуктів управлінської праці та усвідомлювати їхню значимість для ефективної діяльності як представницького органу в цілому, так і кожного підлеглого співробітника зокрема.

- Усвідомлювати, розуміти, характеризувати управлінську працю представницького лідера як безперервний процес формування взаємозацікавлених союзників та послідовників 3 числа підлеглих та зацікавлених громадян.

- Розуміти сучасну роль і значення керівника як організатора та керманича спільної діяльності колективу співробітників-однодумців.

- Уміти здійснювати об'єктивно-критичний аналіз власної особистості як основи безперервного процесу самоменеджменту, що поєднує такі обов'язкові складові: самоусвідомлення, самоаналіз, 
самооцінювання, саморозвиток, самовдосконалення, самореалізація, самоактуалізація [2].

- Уміти аналізувати управлінську діяльність не лише як сукупність дій суб'єкта управління, спрямовану на якісні зміни об'єкта управління у заданому напрямі, а й безперервний процес організації i здійснення цілеспрямованої суб'єкт-об'єктної взаємодії заради досягнення соціально значимих результатів.

Очевидно, що представницьке лідерство передбачає володіння певним набором умінь та навичок, необхідних суб'єкту владних повноважень для успішної управлінської діяльності та ефективної взаємодії зі співробітниками та громадянами.

У зв'язку 3 цим, пріоритетності, на нашу думку, набуває актуалізація основних груп умінь та навичок як основи ефективної та результативної лідерської управлінської діяльності у представницьких органах влади:

1. Оптимізація процесу управління:

- визначення чисельності підлеглих, необхідної для виконання роботи;

- постановка цілей та визначення пріоритетів у роботі підлеглих;

- визначення повноважень та відповідальності співробітників.

2. Формування єдиної команди:

- трансформація колективу підлеглих на ефективну команду;

- забезпечення адекватних умов для успішної роботи команди співробітників;

- формування сприятливого

- позитивне налаштування членів команди на взаємозацікавлену співпрацю та партнерство.

3. Аналіз проблеми та прийняття рішень:

- збір та аналіз інформації для виявлення існуючих проблем;

- правильний вибір методів підготовки управлінських рішень;

- розробка критеріїв оцінки альтернативних рішень.

4. Обмін інформацією з підлеглими та керівницттвом:

- письмові розпорядження, звіти;

- проведення нарад, зборів;

- міжособистісне спілкування.

5. Підтримка дисиипліни: 
- доведення до працівників вимог до робочої поведінки та роботи;

- контроль за роботою підлеглих;

- формування організаційної культури, яка містить моделі трудової поведінки та прийняття адміністративних заходів до порушників.

6. Мотивація праці підлеглих: цілей;

- здатність організувати підлеглих на досягнення поставлених

- уміння використовувати засоби матеріального та морального стимулювання;

- створення мотивуючого середовища для підвищення рівня задоволеності підлеглих професійною діяльністю та міжособистісною комунікацією, що сприяє посилення бажання працювати 3 високою віддачею.

7. Раціоналізація власної управлінської пращуі:

- планування власного часу та щоденної роботи;

- планування кар'єри;

- уміння підтримати високий рівень працездатності;

- уміння долати негативні наслідки стресу;

- уміння володіти своїми емоціями та почуттями.

Таким чином, на нашу думку необхідно акцентувати увагу на низці позицій, а саме:

- В сучасних умовах зростаючої вагомості та значимості для системи публічного управління представницьких органів влади така управлінська діяльність офіційно має бути визнана представницьким лідерством.

- Сучасна пріоритетність представницького лідерства посадових осіб та депутатів усіх рівнів постає умовою успішної реалізації процесів децентралізації державної влади.

- Представницьке лідерство жодним чином не може бути зведене до банальної адміністративної моди, бюрократичної галочки чи популістичної видимості професійної діяльності.

\section{Література:}

1. Пашко Л.А. До проблеми резонансного лідерства посадових осіб місцевого самоврядування. Науково-інформаиійний вісник з державного управління. 2014. № 2. С. 17-19. 
2. Пашко Л.А. Самокоучинг як передумова успішності лідерства посадових осіб місцевого самоврядування. Публічне управління та адміністрування: розвиток $i$ впровадження: матеріали наук.-практ. конф. молодих вчених за міжнар. участю (Київ, 17 листоп. 2016 р.). К.: НАДУ, 2016. С. 123-125.

DOI https://doi.org/10.30525/978-9934-26-045-2-9

\title{
ДО ПИТАННЯ КОНЦЕПТУАЛЬНИХ ПІДХОДІВ ВЗАСМОДІЇ СУБ'СКТІВ ЗАКОНОДАВЧОЇ ІНІЩІАТИВИ 3 ОРГАНАМИ ДЕРЖАВНОЇ ВЛАДИ ТА СУДДІВСЬКОГО ВРЯДУВАННЯ В УКРАЇНІ
}

\author{
Плакса В. I. \\ аспірант кафедри парламентаризму та політичного менеджменту \\ Начіональної академії державного управління \\ при Президентові України \\ м. Київ, Украӥна
}

Право законодавчої ініціативи в Україні належить Президентові України, народним депутатам України та Кабінету Міністрів України (стаття 93 Конституції України [1]). Самостійною гілкою влади відповідно до Конституції України проголошено судову владу, проте вона (органи судової влади) не має права законодавчої ініціативи в парламенті України. Поряд з цим Основний Закон визначає, що в Україні діє Вища рада правосуддя (стаття 131), яка є незалежним конституційним органом державної влади та суддівського врядування, який діс в Україні на постійній основі для забезпечення незалежності судової влади, iї функціонування на засадах відповідальності, підзвітності перед суспільством, формування доброчесного та високопрофесійного корпусу суддів та яка наділена повноваженням щодо надання надає обов'язкові до розгляду консультативні висновки щодо законопроектів з питань утворення, реорганізації чи ліквідації судів, судоустрою і статусу суддів, узагальнює пропозиції судів, органів та установ системи правосуддя стосовно законодавства щодо їх статусу та функціонування, судоустрою і статусу суддів [2]. Схожими повноваженнями наділений Верховний Суд в особі Пленуму Верховного Суду (колегіальний орган, до складу якого входять всі судді 